\title{
Assessment of Insect Spectrum, and Insect-Induced Damage at Different Growth Stages of Cucumber (Cucumis sativus L.) In A Rainforest Transition Zone Of Nigeria
}

\section{Olufemi Olutoyin Richard Pitan and Caroline Oyindamola Filani}

Department of Crop Protection, Federal University of Agriculture, Abeokuta, Nigeria

\section{ABSTRACT}

In Nigeria, published information on the range and relative importance of different pests on cucumber is scanty. Studies were therefore carried out in a survey to determine the insects associated with cucumber, and on-field to quantify insectinduced damage at different crop growth stages. Surveys were carried out in five cucumber fields each at Ibadan, Oyo State, and Abeokuta, Ogun State, Nigeria. In the field experiment, cucumber plants were protected at different stages: preflowering, flowering, post-flowering/fruiting, or all growth stages with lambdacyhalothrin sprayed weekly at $25 \mathrm{~g}$ a.i/ha. The control plots were without insecticide protection. Insects recorded from the surveys included: Zonocerus variegatus, Podagrica uniforma, Aphis gossypii, Myzus persicae, Bemisia tabaci, Thrips tabaci, Epilachna chrysomelina, and fruit flies Bactrocera invadens and Dacus ciliatus. Other insects found were Cheilomenes lunata and Chelisoches flavipennis, which are natural enemies of whiteflies and aphids, respectively, and the honey bees, Apis meliferae, which is a pollinator. Significantly higher number and heavier fruits, which were not statistically different from those recorded in full protection plots, were produced when cucumber was protected at post-flowering stage. Fruit fly damage in unprotected plots was $60 \%$ and 55\%, while that of the Epilachna beetle was 55\% and 46\% in 2004 and 2009, respectively. Yield was significantly higher by $50 \%$ in plots sprayed at post-flowering stage over the control. Epilachna beetle and the fruit flies attacking at the post-flowering/fruiting stage are therefore, important in cucumber production, and the fruiting stage is the most critical where insect pest control measures must be applied.

KEYWORDS: control, cucumber, lambda-cyhalothrin, insects, damage, Epilachna chrysomelina, Dacus spp. and Bactrocera spp.

Correspondence: O.O.R Pitan Address: Department of Crop Protection, University of Agriculture, Abeokuta, Nigeria E-mail: femipitan@yahoo.com Tel No. +2348034705372 


\section{INTRODUCTION}

Cucumber, Cucumis sativus L., is the second most important vegetable crop (after watermelon) of the Family Cucurbitaceae, which comprises 90 genera and 750 species (Ekwu et al., 2007). There are evidences that the cucumber originated in India, spread westward and became popular throughout the Egyptian and the Greco-Roman empires (Nonnecke, 1989). The crop is cultivated in most parts of northern and eastern Nigeria by peasant farmers (Ekwu et al., 2007). Cucumber is widely consumed fresh and as a processed product. They are used as low-income sources of vitamins and minerals lacking in most tropical diets (Fashina et al., 1997). It is an indispensable salad recipe and also the basis of extensive pickling industry (Nonnecke, 1989). When used fresh in salads, they can be sliced, diced or cubed. Also, they are fresh pickled, brine pickled with dill, or pickled with sweet, sour, or herb flavouring in varied ways depending upon ethnic and regional taste preferences (Nonnecke, 1989). The fruit of cucumber contains $95 \%$ water, $0.7 \%$ protein, $0.12 \%$ fat, $3-4 \%$ carbohydrate, $0.4 \%$ fibre, $0.4 \%$ ash, vitamins and minerals. The seed kernels contain approximately $42 \%$ oil and $42 \%$ proteins (Fashina et al., 1997).

Cucumber shares with the cucurbit family a high degree of sensitivity to frost and even to lowered freezing temperatures particularly in the fall (Nonnecke, 1989). It requires a warm climate for maximum production, and in cool temperate countries they are usually grown in glass houses. The optimum temperature for growth is about $30^{\circ} \mathrm{C}$ and the optimum night temperature is between $17^{\circ} \mathrm{C}-21^{\circ} \mathrm{C}$ (Ekwu et al., 2007).

Cucumber, like other plants in the Family Cucurbitaceae, is susceptible to insect attack from seedling to fruiting stage. In Nigeria, published information on the range and relative importance of different pests on cucumber and appropriate control measures is still scanty. This information is needed to determine the target pests and the most critical phenological stage at which control measures must be applied so as to reduce cost of inputs and ensure judicious use of chemical insecticide. Similarly, determining the importance of an insect in any agro-ecosystems, contributes to the description of its status. Such information is necessary for the formulation of a good pest management strategy. The objective of this study therefore, were to determine the insects associated with cucumber in south western Nigeria, and assess insect-induced damage at different growth stages of cucumber. 


\section{MATERIALS AND METHODS}

The study was carried out in two experiments. Experiment 1 consisted of field surveys carried out once in May, 2004 to five cucumber fields each at Ibadan, Oyo State, and Abeokuta, Ogun State Nigeria both in rainforest transition zone. The cucumber variety cultivated at the survey sites was Marketmore, and were at different growth stages during the visits. Observations were made from the middle rows of the fields at the survey sites. For the fruit flies, infested fruits were brought back to the laboratory and kept until the emergence of adults, which were used for identification. Observation on other insects was done visually. They were kept in glass vials and brought back to the laboratory for identification. A few of the common insects were identified by the major author on the basis of comparisons with paratype collections at the Federal University of Agriculture, Abeokuta, while others were identified by specialists at the University of Ibadan, Ibadan, Nigeria.

In Experiment 2, a field experiment was carried out at the Teaching and Research Farm of the Federal University of Agriculture, Abeokuta, Nigeria $\left(7^{\circ} 15^{\prime} \mathrm{N}, 3^{\circ} 25^{\prime} \mathrm{E}\right.$, and 159 asl) in the late cropping seasons, AugustNovember 2004 and 2009. The sites were located in the rainforest transition zone of south-western Nigeria with an annual rainfall of about $963.3 \mathrm{~mm}$ and characterized by a bimodal rainfall pattern that peaked in June and September with a dry spell in August. The cucumber variety used was "Marketmore" - an open-pollinated variety, resistant to cucumber mosaic virus and cucumber scab.

A Randomized Complete Block Design was used with three replicates. There were five treatments: insecticide protection at (a) pre-flowering stage (3-5 weeks after planting, WAP); (b) flowering stage (6 WAP); (c) post-flowering stage (7-10 WAP); (d) all growth stages (3-10 WAP); (e) no protection (control). Plot size was $3 \mathrm{~m}$ by $4 \mathrm{~m}$ with $2 \mathrm{~m}$ border, while the total plot size was $23 \mathrm{~m}$ by $16 \mathrm{~m}\left(368 \mathrm{~m}^{2}\right)$. Two seeds of cucumber were planted on flat at the spacing of $0.5 \mathrm{~m} \times 1 \mathrm{~m}$. Plants were thinned to one seedling per hill at 10 days after planting. Manual weeding was carried out once every 2 weeks. A basal treatment of NPK Mg (20 - 20 - 20) fertilizer was applied to all the plots at 5 WAP at $200 \mathrm{~kg} / \mathrm{ha}$. The insecticide used for protection was lambda-cyhalothrin (Karate E.C. 2.5/Sygenta Switzerland) and was applied according to manufacturer's recommendation at $25 \mathrm{~g}$ a.i/ha between $6.30-7.30$ am (local time) on a weekly basis using a pneumatic knapsack sprayer. 
The assessment of the population of associated insect pest species commenced at the pre-flowering stage ( 3 WAP), and was based on visual counting on 10 randomly selected plants from the middle row of each plot. This sampling procedure took place before spraying, on weekly basis till fruit maturity ( $8 \mathrm{WAP}$ ) between 07.30 am and 09.30 GMT (local time) when the insect pests were relatively inactive. Assessment of fruit fly population was at the fruiting stage (7 WAP) and was based on the number of exit holes found on damaged fruits. Larvae found in the fruits were reared to adult stage and were later identified.

Harvesting of cucumber fruits commenced at 8 WAP and lasted till 10 WAP. At harvest, fruits were collected from the 10 selected tagged plants within each plot and sorted out into damaged and undamaged fruits. Fruits with grooves, scarification, tunnels or holes were considered damaged. Damage by Epilachna beetle was characterized by the presence of grooves on fruits, while a fruit was considered to be damaged by the fruit flies if it had one or more exit holes or tunnels along its length and showing frass contamination. Yield evaluation was based on the weight of undamaged fruits.

Data on insect pest population density, damage and yield were subjected to Analysis of Variance (ANOVA) tests at $\mathrm{P}<0.05$ after necessary transformations. Where there were significant differences between the means, Student Newman Keul (SNK) test was used to separate them.

\section{RESULTS AND DISCUSSION}

From the surveys, similar insect species were found associated with cucumber in Ibadan and Abeokuta. A total of 12 species of insects comprising nine insect pests from six insect orders, two predators from two orders and one pollinator were recorded (Table 1). The insect spectrum included variegated grasshopper, Zonocerus variegatus L. (Orthoptera: Acrididae), Podagrica uniforma Jac. (Coleoptera: Chrysomelidae), Aphids Melon aphid (Aphis gossypii Glover) and Green Peach aphid (Myzus persicae Sulzer whitefly, Bemisia tabaci Gennadius (on leaf), Thrips tabaci (Thysanoptera: Thripidae) (on leaf), African melon ladybird beetle Epilachna chrysomelina F (Coleoptera: Coccinellidae) (on leaf and fruit), Bactrocera invadens Drew, Tsuruta \& White (Diptera: Tephritidae). Lesser Pumpkin Fly, Dacus ciliatus Lw. (Diptera: Tephritidae) (on fruits), and the insect predators - Cheilomenes lunata Fab (Coleoptera: Coccinelidae) and Chelisoches flavipennis F. (Demaptera Opisthocosmiidae) (Table 1). 
Table 1. Insects associated with cucumber at Ibadan and Abeokuta, Nigeria from 2004 surveys.

\begin{tabular}{llll}
\hline Insect species & Systematic position & Status & Host/part \\
\hline Zonocerus variegatus L. & Orthoptera: Acrididae & Pest & Leaf \\
Podagrica uniforma Jac. & Coleoptera: Chrysomelidae & Pest & Leaf \\
Aphis gossypii Glover) & Hemiptera: Aphididae & Pest & Leaf \\
Myzus persicae Sulzer & Hemiptera: Aphididae & Pest & Leaf \\
Bemisia tabaci Gennadius & Homoptera: Aleyrodidae & Pest & Leaf \\
Thrips tabaci Lindeman & Thysanoptera: Thripidae & Pest & Leaf \\
Epilachna chrysomelina F & Coleoptera: Coccinellidae & Pest & Leaf and fruit \\
Bactrocera invadens D.T.W. Diptera: Tephritidae & Pest & Fruit \\
Dacus ciliatus Lw. & Diptera: Tephritidae & Pest & Fruit \\
Cheilomenes lunata Fab & Coleoptera: Coccinelidae & Predator & whitefly and aphids \\
Chelisoches flavipennis F & Dermaptera: Opisthocosmiidae & Predator & whitefly and aphids \\
Apis mellifera L. & Hymenoptera: Apidae & Pollinator & Flower \\
\hline
\end{tabular}

Both adult and nymphs of Zonocerus variegatus fed extensively on the leaves making large irregular holes on them. Also, adult $P$. uniforma were observed to chew small round holes (shot holes) in leaves, giving them a sieve-like appearance. Although the damage caused by this pest was minimal, high infestation on young plants, which may not be able to withstand considerable leaf perforation, may be serious. The aphids - $A$. gossypii and M. persicae - and the whiteflies - B. tabaci - were found mainly on the lower leaf surface, where they suck sap. The insects were common; although their adverse effects on cucumber crop were not so apparent, they could be devastating when they transmit cucumber mosaic virus, or at high population levels. Thrips were found on the leaves and they fed by rasping the mouthparts along the surface of leaf tissue, leaving characteristic silvery dots and patches, and some leaf distortion. Both adults and larvae of E. chrysomelina were found feeding on cucumber leaves, flowers and fruits. Fruit damage by the beetle was characterized by the presence of grooves, scarification and patches on fruits. Dacus and Bactrocera spp. that damage fruits through oviposition and larval feeding were also recorded. The fruit fly maggots were found feeding inside the fruit causing sunken, discoloured patches, distortions and open cracks. These cracks may serve as entry points for fungi and bacteria, causing fruit rot. These damage characteristics reduce the market value of attacked fruits. In addition, the larvae (maggots) that develop internally are completely safe from insecticides, making them difficult to control. 
Associated with the pests were two predators, mostly of aphids and whiteflies $-C$. lunata and the earwig, C. flavipennis. The occurrence of $C$. flavipennis and $C$. lunata underscores the need to explore the possibility of using biological control against cucumber pests by investigating the efficiency of these predators on their respective preys. Measures to conserve and increase the population of the natural enemies as well as the enhancement of their activities may be put in place for greater efficiency. The honey bee, A. mellifera, recorded from the survey sites is essential for successful cucumber pollination and production. It is therefore important to conserve bees, and biological agents as much as possible in cucumber production in rainforest areas.

From other countries, important pests of cucumber on the field in the United States of America include spotted cucumber beetles, Diabrotica undecimpunctata and stripped cucumber beetle, Acalymma vittata (Coleoptera: Chrysomelidae) which are both quarantine pests, melon/fruit fly, Bactrocera cucurbitae (Diptera: Tephritidae), squash beetle, Epilachna borealis (Coleoptera: Coccinelidae), pickleworm, Diaphania nitidalis (Lepidoptera: Pyralidae), (Hill, 1987; Munster, 1996; Randall, 2004).

From the field experiments in 2004 and 2009, the pests - Z. variegatus, P. uniforma, E. chrysomelina, the fruit flies (Dacus and Bactrocera spp.), and the predator, Chelisoches flavipennis were the only insects recorded at the experimental site. The beetles (E. chrysomelina), and the fruit flies (Dacus and Bactrocera spp.) constituted the highest populations in both years (Table 2). Relationship analyses also showed that 61 and $68 \%$, and 79 and $72 \%$ of cucumber fruit yield losses were determined by $E$. chrysomelina and the fruit flies (Dacus and Bactrocera spp.) in 2004 and 2009, respectively. They are therefore very important pests of cucumber in the study area (Table 2).

Also, damage caused by the fruit flies and E. chrysomelina was significantly higher in control plots, while the least was recorded in plots sprayed at post-flowering and full spray, compared to others (Table $3 a \& b$ ). In 2004 and 2009, damage by the fruit flies in the control plots were $60 \%$ and $55 \%$, while that of melon beetle was $55 \%$ and $46 \%$, respectively. Fruit weight increased significantly in plots sprayed at post-flowering stage. The values, in both years, were $50 \%$ greater than the control (Tables $3 a \&$ b). Similarly, fruit number increased significantly in plots sprayed at postflowering stage and was not significantly different from that obtained from full protection plots. The values obtained were 32\% and 42\% (2004 and 2009 , respectively) over the control (Tables $3 a \&$ b). 
Table: 2. Insect pest species composition and coefficient of determination of insect population density and cucumber fruit yield reduction in the 2004 and 2009 cropping seasons.

\begin{tabular}{lccccc}
\hline Insect spp. & \multicolumn{3}{c}{ Species ratio (\%) } & & $\mathrm{R}^{2}$ \\
\cline { 2 - 3 } \cline { 5 - 6 } & 2004 & 2009 & & 2004 & 2009 \\
\hline Zonocerus variegatus & 13.8 & 11.5 & & 0.04 & 0.07 \\
Podagrica uniforma & 6.4 & 9.1 & & 0.02 & 0.01 \\
Epilachna chrysomelina & 31.7 & 31.5 & & 0.61 & 0.68 \\
Dacus spp. + Bactrocera spp. & 48.1 & 47.9 & & 0.79 & 0.72 \\
\hline
\end{tabular}

$\mathrm{R}^{2}=$ coefficient of determination

Table 3a: Insect-induced damage and fruit yield of cucumber protected at different growth stages in 2004.

\begin{tabular}{lccccccc}
\hline \multirow{2}{*}{$\begin{array}{l}\text { Insecticide } \\
\text { application }\end{array}$} & \multicolumn{2}{c}{ Damage (\%) by } & $\begin{array}{c}\text { Yield } \\
\text { (kg/ha) }\end{array}$ & $\begin{array}{c}\% \\
\text { increase }\end{array}$ & $\begin{array}{c}\text { Fruit weight } \\
(\mathrm{g})\end{array}$ & $\begin{array}{c}\text { No of } \\
\text { fruits/ha }\end{array}$ & $\begin{array}{c}\% \\
\text { increase }\end{array}$ \\
\cline { 2 - 5 } No spray & $55.4 \mathrm{a}$ & $60.0 \mathrm{a}$ & $11,600 \mathrm{a}$ & - & $0.2 \mathrm{a}$ & $49,300 \mathrm{a}$ & - \\
Pre-flowering & $29.6 \mathrm{~b}$ & $47.0 \mathrm{a}$ & $14,500 \mathrm{~b}$ & 25.0 & $0.3 \mathrm{~b}$ & $46,400 \mathrm{a}$ & -6.0 \\
Flowering & $28.6 \mathrm{~b}$ & $44.0 \mathrm{a}$ & $14,500 \mathrm{~b}$ & 25.0 & $0.3 \mathrm{~b}$ & $52,200 \mathrm{a}$ & 6.0 \\
Post-flowering & $16.7 \mathrm{c}$ & $22.2 \mathrm{~b}$ & $17,500 \mathrm{c}$ & 51.0 & $0.3 \mathrm{~b}$ & $66,700 \mathrm{~b}$ & 35.0 \\
Full spray & $10.0 \mathrm{c}$ & $25.0 \mathrm{~b}$ & $18.500 \mathrm{c}$ & 59.0 & $0.3 \mathrm{~b}$ & $65,000 \mathrm{~b}$ & 32.0 \\
\hline
\end{tabular}

Means along a column with the same alphabets are not significantly different at $\mathrm{P}<0.05$ according to New Duncan's Multiple Range Test (NDMRT).

Table 3b. Insect-induced damage and fruit yield of cucumber protected at different growth stages in 2009.

\begin{tabular}{|c|c|c|c|c|c|c|c|}
\hline \multirow{2}{*}{$\begin{array}{l}\text { Insecticide } \\
\text { application }\end{array}$} & \multicolumn{2}{|c|}{ Damage (\%) by } & \multirow{2}{*}{$\begin{array}{l}\text { Yield } \\
(\mathrm{kg} / \mathrm{ha})\end{array}$} & \multirow{2}{*}{$\begin{array}{c}\% \\
\text { increase }\end{array}$} & \multirow{2}{*}{$\begin{array}{c}\text { Fruit } \\
\text { weight }(\mathrm{g})\end{array}$} & \multirow{2}{*}{$\begin{array}{l}\text { No of } \\
\text { fruits/ha }\end{array}$} & \multirow{2}{*}{$\begin{array}{c}\% \\
\text { increase }\end{array}$} \\
\hline & Beetles & Fruit flies & & & & & \\
\hline No spray & $46.2 \mathrm{a}$ & $55.0 \mathrm{a}$ & $12,300 \mathrm{a}$ & - & $0.2 \mathrm{a}$ & $52,600 a$ & - \\
\hline Pre-flowering & $21.1 b$ & $42.0 \mathrm{a}$ & $15,000 \mathrm{~b}$ & 22.0 & $0.3 b$ & $53,000 \mathrm{a}$ & 0.7 \\
\hline Flowering & $29.0 b$ & $34.0 \mathrm{a}$ & $15,200 b$ & 24.0 & $0.3 b$ & $58,000 \mathrm{a}$ & 10.0 \\
\hline Post-flowering & $11.7 \mathrm{c}$ & $18.0 \mathrm{~b}$ & $18,700 \mathrm{c}$ & 52.0 & $0.3 \mathrm{~b}$ & $74,500 b$ & 42.0 \\
\hline Full spray & $2.0 \mathrm{c}$ & $15.0 \mathrm{~b}$ & $19,000 \mathrm{c}$ & 54.0 & $0.3 b$ & $76,000 \mathrm{ab}$ & 44.0 \\
\hline
\end{tabular}

Means along a column with the same alphabets are not significantly different at $\mathrm{P}<0.05$ according to New Duncan's Multiple Range Test (NDMRT).

A significant marketable yield loss was found to occur due to pests attacking at the reproductive stage. The highest yield $(p<0.05)$ was recorded in plots sprayed at post-flowering stage in both years which was $>50 \%$ greater than the control treatment. This means that the pests attacking at this stage, which were E. chrysomelina, B. invadens and D. 
ciliatus, are the most important in cucumber production in the rainforest transition ecology of Nigeria. The result conforms to McKinley (1992) who reported that $50 \%$ cucurbit production in the South-west Asia was destroyed by fruit flies. The vegetative and flowering pests appeared not to cause any significant yield loss and may be ignored except at high populations. The fruiting stage therefore represents the critical period when pest control measures should be carried out. However, at full protection, yield increase was 59\% and 54\% (in 2004 and 2009, respectively) higher than the control, which was not significantly different from when the crop was protected at post-flowering stage only. Spraying of insecticides all throughout the growing period of cucumber is therefore not advisable as it is tantamount to economic waste.

\section{CONCLUSION}

This study showed that based on the abundance, plant part damaged and severity of damage, Epilachna chrysomelina, the fruit flies - Bactrocera invadens and Dacus ciliatus were considered more damaging than others and are the major insect pests of cucumber in south-western Nigeria. The whiteflies and aphids are also important especially at high populations or when disease organisms are vectored. Secondly, fruiting stage is the most critical of the growth stages of cucumber where control measures have to be adopted. Therefore, adequate integrated management of fruit flies at the fruiting stage is very important to cucumber production.

\section{REFERENCES}

EKWU, L. G., H.O. OSELEBE, and E.O. OKPORIE. 2007. Vegetative growth and yield response of cucumber (Cucumis sativus L) to nitrogen and phosphorus fertilizer. Proceedings of the $20^{\text {th }}$ Annual Conference of Horticultural Society of Nigeria (HORTSON), May 14-17 $7^{\text {th }}, 117-200$.

FASHIMA, A. S. and S.A. ADEKOYA 1997. Comparative effect of farmyard manure on growth and yield of cucumber. Proceedings of the $18^{\text {th }}$ Annual Conference of Horticultural Society of Nigeria (HORTSON), 101 111. 
HILL, D.S. 1987. Agricultural insect pests of temperate regions and their control. Cambridge University Press. United Kingdom .

MCKINLEY R. G. 1992. Vegetable Crop Pests. Macmillan Academic and Professional Ltd,United Kingdom.

MUNSTER, M. J. 2005. Cucumber beetle. North Carolina Co-operative Extension Service.pp.1-3.

NONNECKE, I. L. 1989.Vegetable Production. Van Nostrand Reinhold, N. Y.

RANDALL, P. G. 2004. Cucumber, squash, melon and other cucurbit insects. Clemson University Co-operative Extension Service, 1- 5. 